\title{
Life-history of the parthenogenetic oonopid spider, Triaeris stenaspis (Araneae: Oonopidae)
}

\author{
StanisLav KORENKO, JAKUB ŠMERDA and Stano PEKÁR*
}

Department of Botany and Zoology, Faculty of Sciences, Masaryk University, Kotlářská 2, 61137 Brno, Czech Republic

\begin{abstract}
Key words. Araneae, Oonopidae, Triaeris stenaspis, ontogeny, life cycle, development, fecundity, parthenogenesis, endosymbionts,
\end{abstract} Wolbachia, Cardinium

\begin{abstract}
Selected life-history traits of an oonopid spider, Triaeris stenaspis Simon, which has been introduced into greenhouses in Europe, were investigated. Spiders were reared in the laboratory under constant physical and dietary conditions, and followed from egg to death. The spiders passed through 3 juvenile instars, each lasting approximately a month. The adult stage lasted on average 6 months, which is $54 \%$ of the entire life cycle. The mortality in each juvenile instar was similar. Five morphological characters were recorded for each instar, which provided a reliable means of identifying the developmental stages. All spiders developed into females and although kept isolated they laid fertile eggs, which indicates thelytokous parthenogenesis. Eggs were always enclosed in a disc-shaped egg-sac, each containing 2 eggs. Total fecundity was on average 27 eggs and rate of laying eggs decreased with age. Fecundity was positively correlated with adult longevity. Fertility was rather low, approximately 59\%. It was negatively correlated with fecundity but not related to longevity. Low fertility appears to be the only cost of parthenogenetic reproduction. There was considerable genotypic variation in all traits studied compared to that in sexually reproducing spiders. There were no apparent maternal effects on all the traits studied. Using molecular methods proved that parthenogenesis in T. stenaspis is not induced by the endosymbiotic bacteria, Wolbachia sp. or Cardinium sp.
\end{abstract}

\section{INTRODUCTION}

Parthenogenesis is a rare phenomenon in the animal kingdom. It has been frequently studied in insects (Suomalainen, 1962), but rarely in arachnids. Except for mites, where it is rather common (Helle et al., 1980), it is reported only for a few scorpions (Lourenço, 2002, 2008), harvestmen (Tsurusaki, 1986), schizomids (Reddell \& Cokendolpher, 1995) and amblypygids (Weygoldt, 2007), but there is little reliable information. Of the more than 40000 species of spiders in the world (Platnick, 2008) only a few are parthenogenetic (Lake, 1986; Deeleman-Reinhold, 1986; Gruber, 1990; Shimojana \& Nishihira, 2000; Edwards et al., 2003).

Parthenogenetic reproduction has long been considered to be evolutionary short-lived (White, 1973). It is claimed that the major disadvantage of asexual clones is their inability to adapt to changes in the environment and resist infections (Groot et al., 2005). There is a number of asexual species that are, however, very successful. For example, acaridid mites not only adapt to new hosts but also develop resistence to acaricides (Campos \& Omoto, 2002). Two alternative hypotheses are proposed to explain how asexual populations can adapt to different niches. The General Purpose Genotype model suggests the existence of generalist clones that are ecologically tolerant throughout the entire species range (Lynch, 1984). The Frozen Niche Variation model postulates that the asexual species consists of many specialist clones, each adapted to a particular niche (Vrijenhoek, 1979).
A species can benefit from parthenogenesis. Parthenogenetic species are considered superior colonizers as they are able to establish a new population in isolation and away from their bisexual progenitors (Cuellar, 1977; Lourenço, 2008). Parthenogenetic animals do not waste eggs producing male progeny, have no mating costs and possess a higher reproductive potential (White, 1973). All of this can give rise to successful species expansion. For example, recently a parthenogentic scorpion Tityus serrulatus Lutz \& Mello was introduced into Brazil, which displaced a related bisexual species, Tityus fasciolatus (Pessõa) (Lourenço, 2002).

There are several ways in which parthenogenesis can evolve. Cytologically parthenogenesis can be apomictic (ameiotic), automictic (meiotic) or generative (haploid) (Suomalainen, 1962). Recently, it was discovered that the latter type can be induced by maternally inherited endosymbiotic bacteria, such as Wolbachia and Cardinium. These bacteria have been detected in many insects and shown to affect their mode of reproduction (Weeks et al., 2002; Zchori-Fein \& Perlman, 2004). Very recently these endosymbiotic bacteria have been detected in a number of spider species (Goodacre et al., 2006), but their effect on spider reproduction is unknown.

This study focused on an oonopid spider, Triaeris stenaspis Simon, which was introduced into greenhouses in central and western Europe (Korenko et al., 2007). Oonopid spiders are rare in Europe, occuring mostly in the tropics (Platnick, 2008). Little is known about the natural history of these species (Burger et al., 2006) as

\footnotetext{
* Corresponding author: pekar@sci.muni.cz
} 
none of them has been subjected to a detailed study. $T$. stenaspis was first described from the Caribbean island of St. Vincent (Simon, 1891) and according to Platnick (2008) is distributed from USA to Venezuela, including the West Indies. Only females of this species are known and Koponen (1997) suggested that it is parthenogenetic.

The aim of this study was to (1) investigate in detail the life-history of $T$. stenaspis, (2) determine its mode of reproduction, (3) reveal how its life-history traits are affected by parthenogenesis, and (4) determine whether parthenogenesis is caused by bacterial endosymbionts.

\section{MATERIAL AND METHODS}

\section{Development and reproduction}

Adult females $(\mathrm{N}=3)$ of $T$. stenaspis were collected from a greenhouse in the Botanical Garden of the Masaryk University, Brno, Czech Republic. These females laid several eggs from which 68 spiderlings hatched. These were used in this study, which lasted for 10 months. Spiderlings were placed singly in cylindrical containers (diameter $35 \mathrm{~mm}$, height $40 \mathrm{~mm}$ ) with a layer of plaster of Paris at the bottom. They were kept at room temperature, $22 \pm 3.5^{\circ} \mathrm{C}$. The plaster was moistened every 10 days. Spiders were fed a surplus of springtails (Sintela sp. and Sinella curviseta Brook) every 5 days.

Our observations focused on the development after emergence from the egg-sac, i.e. beginning with the first free instar. Each spider was monitored until it died. For each individual the number of moults, duration of individual instars and mortality were recorded by checking the spiders at $1-5$ day intervals. For adults their longevity, time to oviposition, production of eggs and their time to hatching were recorded. Fecundity was expressed as the total number of eggs produced during a female's life and fertility as the proportion of eggs that hatched.

\section{Morphological characters}

For each instar the following parameters were measured: (1) length of prosoma (along longest axis), (2) outer width of anterior eye region, (3) length of tibia I, (4) number of ventral spines on patella I, (5) number of ventral spines on tibia I and (6) the number of abdominal scuta. All these parameters were assumed to be stage specific. The number of spines is, for example, an important character used in the identification of oonopid spiders (Chickering, 1969). In addition the size of eggs and egg-sacs (longest axis) were measured. All measurements were done under a stereomicroscope, Olympus SZX9.

\section{Analyses}

Statistical analyses were conducted within $\mathrm{R}$ environment ( $\mathrm{R}$ Development Team, 2007). The confidence intervals for prediction of future measurements of prosoma length, anterior eye region width and tibia length were estimated from a linear model based on a normal distribution of the measurements. Survival was estimated by means of the Kaplan-Meier method implemented within the survival package (Therneau \& Lumley, 2007). Mortality for particular instars was compared using a 3 -sample test for equality of proportions. As the variance of the data was homogeneous the relationships between selected traits were studied using linear regression (LM) with normal errors. The temporal change in the rate of egg laying, production of empty sacs and fertility was modelled using Generalised Least Squares (GLS) in the nlme package (Pinheiro et al., 2006) in order to test for autocorrelation in the data. If there was no autocorrelation of the AR1 process, LM or Generalised Linear Models with binomial errors (GLM) were used. For each trait a coefficient of variation (CV) was used to estimate the variability. CV was computed according to the standard formula for the coefficient of variation multiplied by $100 \%$. Maternal effects were analysed either using ANOVA for continuous measurements (e.g., duration of instars) or GLM with binomial errors for proportions (fertility).

\section{Endosymbionts}

Ten individuals were screened for the presence of two endosymbionts using PCR with species-specific primers for Wolbachia and Cardinium. Spider DNA was extracted using the Promega Wizard Genomic DNA Purification Kit according to the manufacturer's instruction. DNA was extracted from legs to exclude the possibility of false-positive samples resulting from ingested prey and decrease redundant inhibitors of PCR from abdomen. The DNA quality was tested by amplification of eukaryotic 18S rRNA gene using the universal primers NSF4/18 and NSF399/19 (Hendriks et al., 1989, 1991). Cardinium infections were detected using $\mathrm{ChF}$ (Zchori-Fein \& Perlman, 2004) and CLO-r1 (Gotoh et al., 2007) primers, and Wolbachia infections by $16 \mathrm{Swolb} 76-99 \mathrm{f}$ and $16 \mathrm{Swolb} 1012-994 \mathrm{r}$ primers (O'Neill et al., 1992). The $20 \mu \mathrm{l}$ PCR mix consisted of 30-50 ng DNA, $1 \times$ PCR buffer, $1.5 \mathrm{U}$ Taq DNA polymerase, $2.4 \mathrm{mM}$ $\mathrm{MgCl}_{2}, 100 \mu \mathrm{M} \mathrm{dNTP}$ and $250 \mathrm{nM}$ of each primer. Thermal conditions for amplification of all PCRs were $94^{\circ} \mathrm{C}$ for $2 \mathrm{~min}$ and 35 cycles of $94^{\circ} \mathrm{C}$ for $30 \mathrm{~s}, 54^{\circ} \mathrm{C}$ for $30 \mathrm{~s}$ and $72^{\circ} \mathrm{C}$ for 1 min, followed finally by $72^{\circ} \mathrm{C}$ for $5 \mathrm{~min}$.

\section{RESULTS}

\section{Development}

After leaving the egg-sac the spiderlings required 3 moults to reach maturity. The first instar lasted on average 31.5 days $(\mathrm{SD}=9.8, \mathrm{~N}=51, \mathrm{CV}=31.1 \%)$, the second 29.8 days $(\mathrm{SD}=6.9, \mathrm{~N}=37, \mathrm{CV}=23.2 \%)$ and the third 24.5 days $(\mathrm{SD}=5.3, \mathrm{~N}=31, \mathrm{CV}=21.6 \%)$. Thus the duration of juvenile instars decreased with age. Average longevity of adults was 101 days $(\mathrm{SD}=46.4, \mathrm{~N}$ $=31, \mathrm{CV}=45.9 \%$ ), with a maximum of 201 days. Longevity was not related to the duration of juvenile development $\left(\mathrm{LM}, \mathrm{F}_{1,29}=0.01, \mathrm{P}=0.9\right.$ ). The total life-span (from

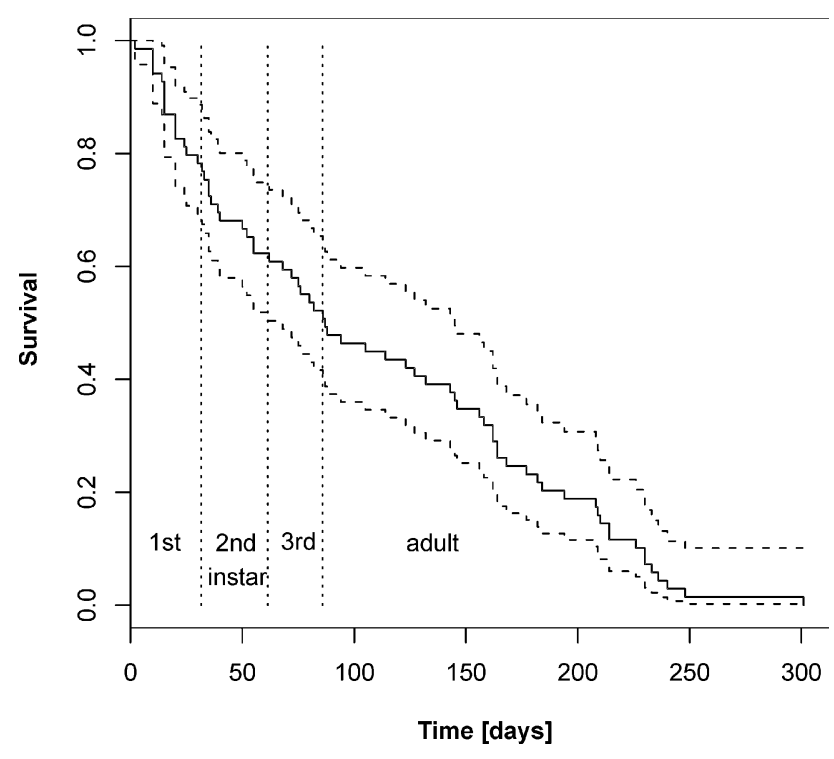

Fig. 1. Survival (-) of $T$. stenaspis $(\mathrm{N}=69)$ from hatching to adulthood. Dashed lines are the $95 \%$ confidence intervals. Vertical dotted lines indicate the means of the times of moulting. 


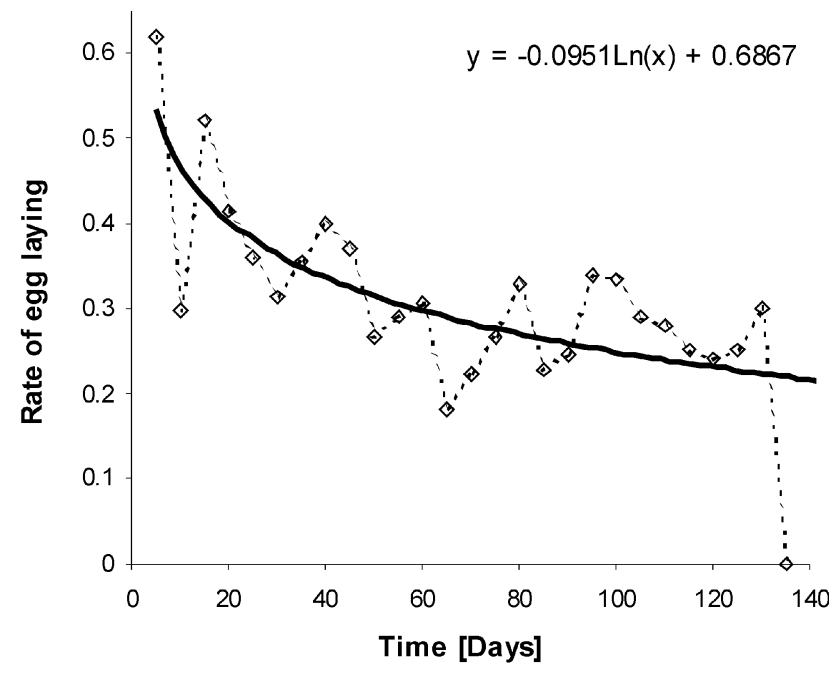

Fig. 2. Temporal changes in the rate of egg laying, expressed as the average number of eggs produced by a female per day during its life $(\mathrm{N}=31)$. Linear model is presented.

hatching to death) lasted on average 182 days $(\mathrm{SD}=46.4$, $\mathrm{N}=31$ ) and generation time (from hatching to egg-laying) was on average 97.5 days $(\mathrm{SD}=9.4, \mathrm{~N}=31)$. For none of these traits was there a significant maternal effect (ANOVA, P > 0.1).

Survival was similar in all juvenile stages (Proportion test, $\left.\chi^{2}{ }_{2}=1.5, \mathrm{P}=0.48\right)$, ranging between 74 and $84 \%$ (Fig. 1), and independent of the mother (Proportion test, $\left.\chi_{2}^{2}=0.6, \mathrm{P}=0.74\right)$.

\section{Morphological characters}

The size of the prosoma, tibia I and anterior eye region increased with the stage (Table 1). The 95\% CI for predictions of length of tibia do not overlap between subsequent instars. The number of spines differed between stages. In the first instar there were 2 pairs of ventral spines on patella I and 3 pairs on tibia I, in later instars there were 3 and 5 pairs of spines, respectively (Table 1).

All juvenile instars were pale in colour and their coloration depended on the food. Red-yellowish coloration with three reddish-brown scuta (dorsal, epigastric and ventral) on opisthosoma was only present at maturity.

TABLE 1. The means and 95\% CI (for predicting measurements) of five parameters: length of prosoma (Prosoma), width of anterior eye region (AER), length of tibia I (Ti), number of pairs of ventral spines on tibia I (Ti), number of pairs of ventral spines on patella I $(\mathrm{Pt})$ and number of abdominal scuta (Scuta). $\mathrm{N}=10$ for all parameters.

\begin{tabular}{|c|c|c|c|c|c|c|}
\hline Stage & $\begin{array}{l}\text { Prosoma } \\
\text { (mm) }\end{array}$ & $\operatorname{AER}(\mathrm{mm})$ & Ti (mm) & Ti I & $\mathrm{Pt}$ & Scuta \\
\hline 1 st instar & $\begin{array}{c}0.482 \\
(0.448,0.516)\end{array}$ & $\begin{array}{c}0.106 \\
(0.096,0.115)\end{array}$ & $\begin{array}{c}0.190 \\
(0.174,0.205)\end{array}$ & 3 & 2 & 0 \\
\hline 2nd & $\begin{array}{c}0.527 \\
(0.493,0.561)\end{array}$ & $\begin{array}{c}0.123 \\
(0.113,0.133)\end{array}$ & $\begin{array}{c}0.239 \\
(0.223,0.254)\end{array}$ & 5 & 3 & 0 \\
\hline 3rd instar & $\begin{array}{c}0.643 \\
(0.609,677)\end{array}$ & $\begin{array}{c}0.149 \\
(0.139,0.159)\end{array}$ & $\begin{array}{c}0.319 \\
(0.304,0.335)\end{array}$ & 5 & 3 & 0 \\
\hline Adult & $\begin{array}{c}0.709 \\
(0.675,0.743\end{array}$ & $\begin{array}{c}0.173 \\
0.163,0.182 \\
\end{array}$ & $\begin{array}{c}0.383 \\
(0.368,0.399)\end{array}$ & 5 & 3 & 3 \\
\hline
\end{tabular}

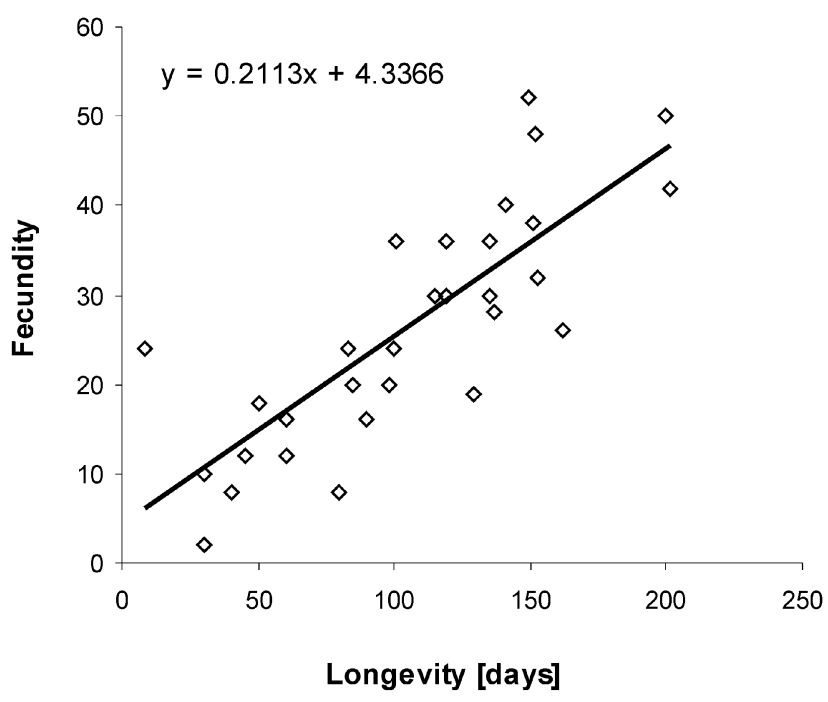

Fig. 3. Relationship between fecundity (total number of eggs laid) and adult longevity. Linear model is presented.

\section{Reproduction}

All the spiders developed into females $(\mathrm{N}=31)$. Despite being kept isolated during their entire life they all began to lay fertile eggs on average 14.1 days $(\mathrm{SD}=5.6$, $\mathrm{N}=31, \mathrm{CV}=39.7 \%$ ) after the last moult. The eggs were enclosed in disc-shaped pinkish silken sacs. Each egg-sac contained 2 eggs. The spiders laid on average 0.306 eggs per day $(\mathrm{SD}=0.108, \mathrm{~N}=31)$, which decreased with age (LM, $\mathrm{F}_{1,26}=27.6, \mathrm{P}<0.0001$, Fig. 2). The total fecundity was on average 27.4 eggs $(\mathrm{SD}=13.1, \mathrm{~N}=31, \mathrm{CV}=$ $47.8 \%$ ), with two eggs in each egg-sac. There was a positive linear relationship between fecundity and longevity (LM, $\mathrm{F}_{1,29}=51.2, \mathrm{P}<0.0001$, Fig. 3).

Fertility was negatively related to fecundity (LM, $\mathrm{F}_{1,29}=$ $7, \mathrm{P}=0.012$, Fig. 4) and was on average $0.59(\mathrm{~N}=31)$. Fertility was not related to longevity $\left(\mathrm{LM}, \mathrm{F}_{1,29}=0.25, \mathrm{P}\right.$ $=0.62$ ). Fertility declined slightly with successive egg-

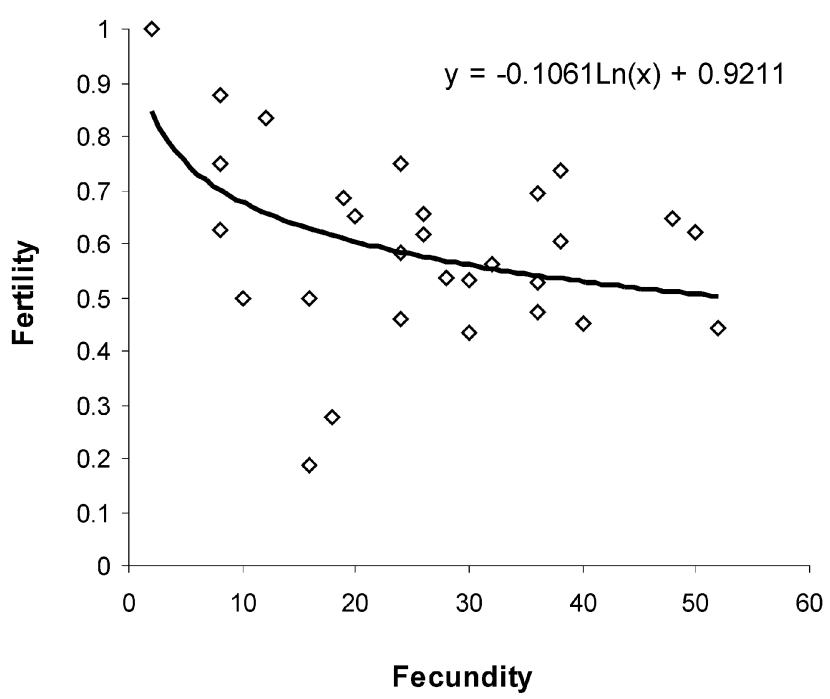

Fig. 4. Relationship between fertility (proportion of eggs that hatched) and fecundity (total number of eggs laid). Linear model is presented. 


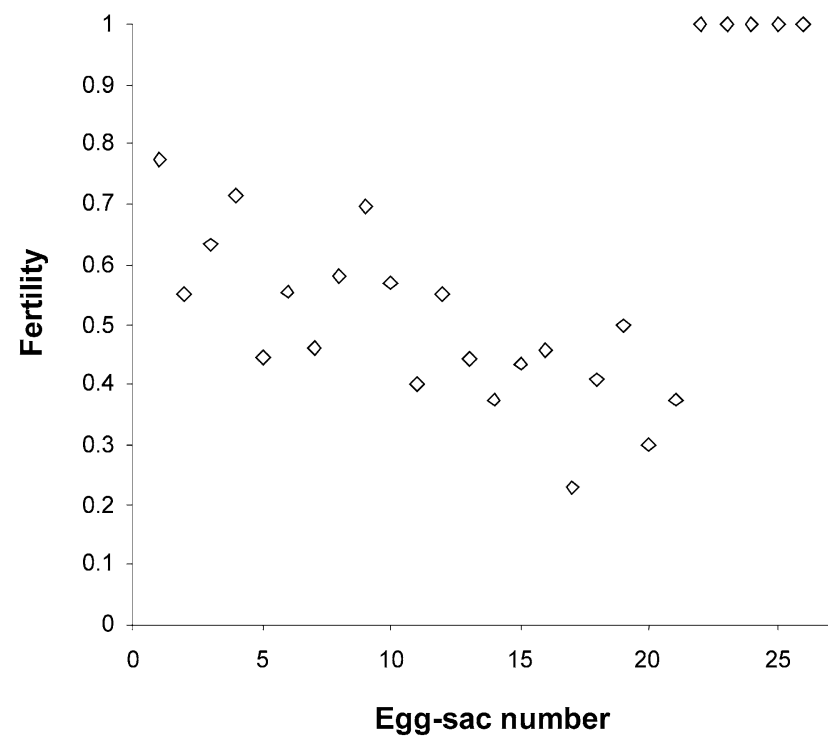

Fig. 5. Temporal changes in the average proportion of eggs that hatched in the successive egg-sacs produced by 31 females.

clutches, but not significant so $\left(\mathrm{GLS}, \mathrm{F}_{1,418}=3.5, \mathrm{P}=\right.$ 0.06 , Fig. 5). In fact, the fertility of the last egg clutches of the few individuals that produced many egg clutches was high. Fecundity, time to production of first egg-sac and fertility were independent of the mother (ANOVA or GLM, P > 0.14).

The average egg-sac was $1.45 \mathrm{~mm}(\mathrm{SD}=0.1, \mathrm{~N}=10)$ long. Eggs were on average $0.47 \mathrm{~mm}(\mathrm{SD}=0.01, \mathrm{~N}=10)$ in diameter. Incubation time of eggs was on average 32.7 days $(\mathrm{SD}=5.4, \mathrm{~N}=22, \mathrm{CV}=16.5 \%)$. In addition to producing egg-sacs they also produced empty sacs, i.e. only the basal disc. The production of empty sacs increased with age (GLM, $\chi^{2}{ }_{1}=38.4, \mathrm{P}<0.0001$, Fig. 6$)$.

\section{Endosymbionts}

The fragment of eukaryotic 18S rDNA gene from all samples was amplified, which indicated satisfactory DNA quality. Neither Wolbachia nor Cardinium were detected in the tissue samples.

\section{DISCUSSION}

At present few species of spider are thought to be parthenogenetic and only for two of them is there laboratory evidence. Suggestive evidence is available for two other species. A single juvenile female of a sparassid, Holconia insignis (Thorell), kept in isolation after its final moult laid a single egg-sac from which spiderlings hatched (Lake, 1986). Another instance is the troglobiontic amaurobiid, Coelotes troglocaecus Shimojana \& Nishihira, which is found in limestone caves on Okinawa Island (Japan) and the populations of which consist only of females. That this spider lives in a isolated habitat in caves, at low population densities, in the absence of males and has degenerate reproductive organs (spermathecae and spermathecal ducts) strongly suggest reproduction by thelytokous parthenogenesis (Shimojana \& Nishihira, 2000). There is laboratory evidence of parthenogenesis, based on experimental rearing of individuals in isolation,

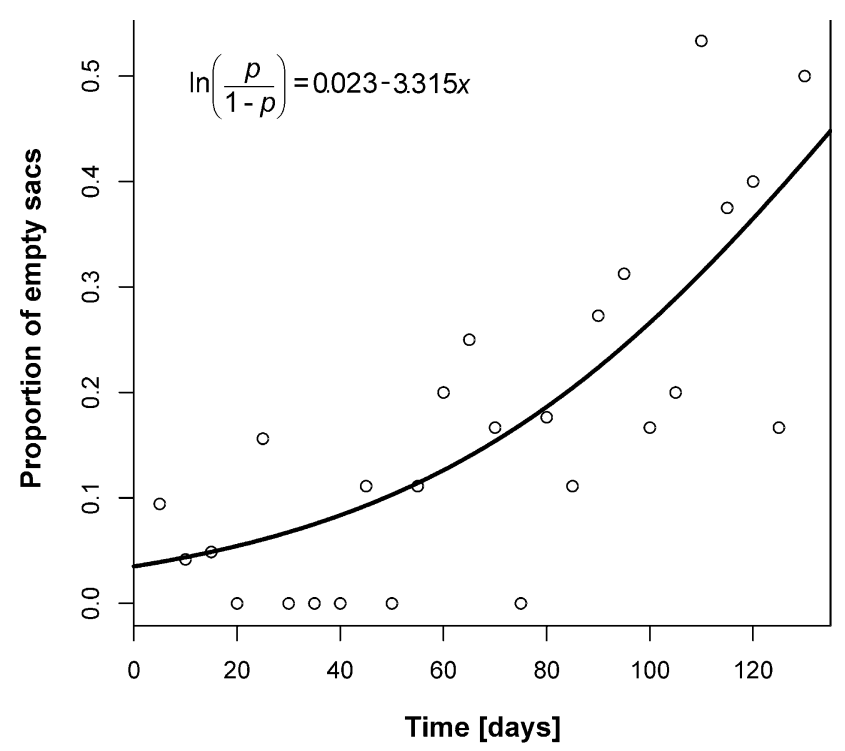

Fig. 6. Temporal changes in the proportion of empty sacs produced by females $(\mathrm{N}=17)$. The logit model, where $p$ is the proportion of sacs and $x$ is time, is presented.

for only two species of spider. Machado (1964) was the first to suggest parthenogenesis in the orychoceratid Theotima minutissima (Petrunkevitch), which was only recently experimentally confirmed by Edwards et al. (2003). Deeleman-Reinhold (1986) suggested that a local parthenogenetic population of Dysdera hungarica Kulczyński existed in Europe. Sexual populations occur only in the eastern part of its range, in the Transylvanian mountains and northern Bulgaria. Parthenogenesis was experimentally confirmed in this species by Gruber (1990).

It is unknown whether T. stenaspis is also parthenogenetic in its native area, the Carribic, as the male of this species has not yet been found (Platnick, 2008). Unlike $C$. troglocaecus, but similar to D. hungarica, females of $T$. stenaspis possess fully developed copulatory organs (Korenko et al., 2007). This suggests that reproduction by parthenogenesis might only occur in geographically isolated populations.

We thought that parthenogenesis might be induced in these allopatric populations as a result of infection by some endosymbiotic bacteria (Weeks et al., 2002). However, neither Wolbachia or Cardinium were detected in $T$. stenaspis tissues. Preliminary results indicate automictic parthenogenesis as meiosis still occurs. The diploid number of holocentric chromosomes $(2 n)$ is 8 and the likely sex determination system XX (J. Král \& J. Musilová, pers. comm.).

To determine the effect of parthenogenesis on the life history a sexual population of the same species needs to be studied. As males are not known in T. stenaspis a closely related species could be used. However, there is not a single study on the life-history of any other oonopid spider. Therefore, observed traits had to be compared with those of an unrelated species of spider.

The number of instars depends mainly on spider size (Schaefer, 1987). T. stenaspis is on average $2 \mathrm{~mm}$ long. 
Three juvenile instars is the number recorded for other tiny species of spider (e.g., Schaefer, 1987; Rybak, 2007). But T. minutissima has at least 5 juvenile instars, though it is only $0.9 \mathrm{~mm}$ long (Edwards et al., 2003). The number of instars often depends on environmental conditions (e.g., Higgins \& Rankin, 1996). We did not record any variation in the number of instars, which suggests that this trait might be canalised in $T$. stenaspis. The intermolt interval, however, was very variable suggesting it is plastic. A similar developmental trajectory, with both plastic and canalised traits, is reported for a few other spiders (Higgins \& Rankin, 1996). As all the T. stenaspis were reared under similar physical conditions (temperature and humidity) this variation must be mainly due to genotypic variation. All individuals were provided with a surplus of springtails, which are presumably the main prey of this spider.

Survival is affected by both intrinsic (e.g., nutrition, hunger) and extrinsic (predation, disease, competition, temperature, moisture) factors. Studies of survival of spiders under natural conditions reveal survivorship curves of type II and III (Tanaka, 1992; Boulton \& Polis, 1999). For $T$. stenaspis a survivorship curve of type I was recorded. This is typical for species in which mortality is concentrated towards the end of their life. This is obviously because $T$. stenaspis was reared under constant laboratory conditions, which filtered out the effects of many extrinsic and intrinsic variables.

Like the rate of development, fecundity is influenced by physical conditions (e.g., Downes, 1988), prey quality and quantity (Mayntz et al., 2005). Females of $T$. stenaspis laid egg clutches composed only of two eggs, but produced many egg clutches. Other similar small sized species of spider have a different reproductive strategy: they produce few egg-sacs each containg several eggs. For example, the linyphiid Bathyphantes simillimus (L. Koch) produces 6 egg-sacs each containing an average of 11 eggs (Rybak, 2007). Edwards et al. (2003) record that the parthenogenetic females of the tiny $T$. minutissima produce 1-2 egg-sacs each containing an average of 5 eggs.

Several models of the relationship between reproductive parameters, such as fecundity, egg size, number of egg-sacs and body size or body mass of females have been proposed. The model proposed by Marshall \& Gittleman (1994) for the relationship between fecundity and the mass of females predicts fewer egg-sacs for $T$. stenaspis than were recorded. That of Simpson (1995) predicts a smaller total fecundity and larger eggs than recorded. The low number of eggs per egg clutch and their small size in T. stenaspis is presumably a result of an interaction between the size of the eggs and morphological constraints of the abdomen. The abdomen of females has three scuta, which might restrain enlargement of the abdomen during egg development. Iteroparous reproduction (multiple egg-sac production) could have helped this species to spread so successfully.

The rate at which spiders lay eggs decreases with adult age (e.g., Miyashita 1988; Fischer \& Vasconcellos-Neto, 2005b). A similar pattern was observed in T. stenaspis, but in terms of the frequency of egg-sac production as the number of eggs in a sac remained constant (2).

At warmer latitudes spiders tend to be more long-lived, unlike in the temperate zone where many spiders have very short adult lives (Schaefer, 1987). Data for species from warmer climates indicates that the adult stage makes up more than $50 \%$ of the life span. For example, in the sexually reproducing sicariid Loxosceles intermedia Mello-Leitão the adult life span is about $60 \%$ of the total lifespan (Fischer \& Vasconcellos-Neto, 2005a); in $T$. stenaspis it was $54 \%$ and in T. minutissima it is $50 \%$ (Edwards et al., 2003). It is suggested that rapid growth occurs at the expense of longevity. This is not supported by our data.

Fertility, or hatching success, is usually very high, especially of laboratory reared spiders. For example, the fertility recorded for a clubionid (Austin, 1984) and zodariid spider (Pekár et al., 2005) is more than 90\%. In general, in sexual species of spiders fertility correlates positively with the duration of mating (Fischer \& Vasconcellos-Neto, 2005b). In L. intermedia the fertility of the eggs in the first egg-sac is higher than $80 \%$ but is significantly less for those in successive egg clutches (Fischer \& Vasconcellos-Neto, 2005b). In sexually reproducing species this might be due to sperm depletion. In $T$. stenaspis this decrease in the fertility of the eggs in successive egg clutches was recorded only in females that had a short or moderate life-span. The fertility of the females with a long life-span remained constant.

The continuous production of the basal discs of eggsacs is interesting. The production of empty egg-sacs is known to occur in sexually reproducing linyphiid spiders kept under laboratory conditions (S. Toft, pers. comm.). Why females of $T$. stenaspis abandon basal discs is not clear. External factors, such as insufficient food and disturbance by prey are an unlikely cause as the spiders were provided with a surplus of prey and the sacs were placed on the side of the container, an area inaccessible to the prey. The production of such a large number of egg-sacs is presumably far beyond their ability so there has never been a selection for maintaining reproductive capacity for so long (S. Toft, pers. comm.).

Parthenogenetic reproduction is assumed to produce genetically homogeneous clones that vary little (phenotypically or genetically) in their traits. But Asher (1970) showed that even parthenogenesis can sustain genetic plasticity under certain conditions. In this study all individuals were reared under similar conditions, yet there was remarkable variation, ranging between 17 and $48 \%$. We assume this variation is largely genotypic because of the standardised rearing conditions. This range in variation is similar to that recorded for the sexually reproducing L. intermedia (Fischer \& Vasconcellos-Neto, 2005b). Interestingly, the variation between spiderlings from a single mother was as large (or larger) as that between those from different mothers. Thus no maternal effects on traits were recorded. 
The results show that $T$. stenaspis is a parthenogenetic eurychronous, iteroparous species with about 3 generations per year. The maintenance of plasticity in parthenogenetic populations is thought to be costly (Asher, 1970). We identified one cost, low fertility. This cost seems to be negligible compared with the benefits as this species has established viable populations in many greenhouses in Europe (Korenko et al., 2007). Of the 18 species in the genus Triaeris only this one has colonized Europe presumably because of its parthenogenetic mode of reproduction.

ACKNOWLEDGEMENTS. We would like to thank S. Toft for very useful comments on the manuscript. We are greatly indebted to T. Bilde and J.P. Maelfait for the collembola cultures, P. Weygoldt and N.I. Platnick for providing us with copies of some rare papers. This study was supported by grants no. 0021622416 and LC06073 from the Ministry of Education, Youth and Sports of the Czech Republic. SK was supported by grant no. 526/09/H025 from the Czech Science Foundation.

\section{REFERENCES}

AsHeR J.H. 1970: Parthenogenesis and genetic variability. II. One-locus models for various diploid populations. Genetics 66: $369-391$.

Austin A. 1984: Life history of Clubiona robusta L. Koch and related species (Araneae, Clubionidae) in South Australia. $J$. Arachnol. 12: 87-104.

Boulton A.M. \& Polis G.A. 1999: Phenology and life history of the desert spider, Diguetia mojavea (Araneae, Diguetidae). J. Arachnol. 27: 513-521.

Burger M., Graber W., Michalik P. \& Kropf C. 2006: Silhouettella loricatula (Arachnida, Araneae, Oonopidae): a haplogyne spider with complex female genitalia. J. Morphol. 267: 663-677.

Campos F.J. \& Омото C. 2002: Resistence to hexythiazox in Brevipalpus phoenicis (Acari: Tenuipalpidae) from Brazilian citrus. Exp. Appl. Acarol. 26: 243-251.

Chickering A.M. 1969: The genus Triaeris Simon (Araneae, Oonopidae) in Central America and the West Indies. Psyche 75: $351-359$.

Cuellar O. 1977: Animal parthenogenesis. Science 197: 837-843.

Deeleman-Reinhold C.L. 1986: Dysdera hungarica Kulczynski - A case of parthenogenesis? In Barrientos J.A. (ed.): Actas X Congresso Internacionale Arachnologia. Instituto Pirenaico de Ecologia, Jaca (Spain), pp. 25-31.

Downes M.F. 1988: The effect of temperature on oviposition interval and early development in Theridion rufipes Lucas (Araneae, Theridiidae). J. Arachnol. 16: 41-45.

Edwards L.E., Edwards E.H. \& Edwards A.D. 2003: Observations of Theotima minutissimus (Araneae, Ochyroceratidae), a parthenogenetic spider. J. Arachnol. 31: 274-277.

Fischer M.L. \& Vasconcellos-Neto J. 2005a: Development and life table of Loxosceles intermedia Mello-Leitão 1934 (Araneae, Sicarridae). J. Arachnol. 33: 758-766.

Fischer M.L. \& VAsconcellos-Neto J. 2005b: Parameters affecting fecundity of Loxosceles intermedia Mello-Leitão 1934 (Araneae, Sicariidae). J. Arachnol. 33: 670-680.

Goodacre S.L., Martin O.Y., Thomas C.F.G. \& Hewitt G.M 2006: Wolbachia and other endosymbiont infections in spiders. Mol. Ecol. 15: 517-527.
Gotoh T., Noda H. \& Ito S. 2007: Cardinium symbionts cause cytoplasmatic incompatibility in spider mites. Heredity $\mathbf{9 8}$ : $13-20$.

Groot T.V.M., Janssen A., Pallini A. \& Breeuwer A.J. 2005: Adaptation in the asexual false spider mite Brevipalpus phoenicis: evidence for frozen niche variation. Exp. Appl. Acarol. 36: $165-176$.

Gruber J. 1990: Fatherless spiders. Newsl. Br. Arachnol. Soc. 58: 3 .

Helle W., Bolland H.R. \& Heitmans W.R.B. 1980: Chromosomes and types of parthenogenesis in the false spider mites (Acari: Tenuipalpidae). Genetica 54: 45-50.

Hendriks L., Goris A., Neefs J.-M., Van de Peer Y., Hennebert G. \& De Wachter R. 1989: The nucleotide sequence of the small ribosomal subunit RNA of the yeast Candida albicans and the evolutionary position of the fungi among the eukaryotes. Syst. Appl. Microbiol. 12: 223-229.

Hendriks L., De Baere R., Van de Peer Y., Neefs J., Goris A. \& De WAChteR R. 1991: The evolutionary position of the rhodophyte Porphyra umbilicalis and the basidiomycete Leucosporodium scotii among other eukaryotes as deduced from complete sequences of small ribosomal subunit RNA. J. Mol. Evol. 32: 167-177.

Higgins L. \& RANKIN M.A. 1996: Different pathways in arthropod postembryonic development. Evolution 50: 573-582.

Koponen S. 1997: Triaeris stenaspis Simon (Araneae, Oonopidae) found in the Botanical Garden of the University of Turku, Finland. Entomol. Fenn. 8: 7.

Korenko S., ŘezÁČ M. \& PekÁr S. 2007: Spiders (Araneae) of the family Oonopidae in the Czech Republic. Arachnol. Mitt. 34: 6-8.

LAKE D.C. 1986: Possible parthenogenesis in the huntsman spider Isopoda insignis (Araneae, Sparassidae). J. Arachnol. 14: 129.

LOURENÇO W.R. 2002: Reproduction in scorpions, with special reference to parthenogenesis. In Toft S. \& Scharff N. (eds): European Arachnology 2000. Aarhus University Press, Aarhus, pp. 71-85.

LOURENÇO W.R. 2008: Parthenogenesis in scorpions: some history - new date. J. Venom. Anim. Toxins Trop. Dis. 14: $19-44$.

LYNCH M. 1984: Destabilizing hybridization, general-purpose genotypes and geographical parthenogenesis. Quart. Rev. Biol. 59: 257-290.

Machado A.B. 1964: Sur l'existence de la parthénogenèse dans quelques espèces d'araignées Ochyrocératides. C.R. Acad. Sci. Paris 258: 5056-5059.

Marshall S.D. \& Gittleman J.L. 1994: Clutch size in spiders: is more better? Funct. Ecol. 8: 118-124.

Mayntz D., Raubenheimer D., Salomon M., Toft S. \& Simpson S.J. 2005: Nutritient-specific foraging in invertebrate predators. Science 307: 111-113.

Miyashita K. 1988: Egg production in Pholcus phalangioides (Fuesslin) (Araneae, Pholcidae) under a constant temperature and photoperiod. J. Arachnol. 16: 126-129.

O’Neill S.L., Giordano R., Colbert A.M.E., Karr T.L. \& RobERTSON H.M. 1992: 16S rRNA phylogenetic analysis of the bacterial endosymbionts associated with cytoplasmic incompatibility in insects. Proc. Nat. Acad. Sci. USA 89: 2699-2702.

Pekár S., Král J., Malten A. \& Komposch C. 2005: Comparison of natural histories and karyotypes of two closely related ant-eating spiders, Zodarion hamatum and Z. italicum (Araneae, Zodariidae). J. Nat. Hist. 39: 1583-1596. 
Pinheiro J., Bates D., DebRoy S. \& Sarkar D. 2006: NLME: Linear and Nonlinear Mixed Effects Models. R Package Version 3.1-77.

Platnick N.I. 2008: The World Spider Catalog, Version 9. American Museum of Natural History, online at http://research.amnh.org/entomology/spiders/catalog/index.ht $\mathrm{ml}$ [accessed August 10, 2008].

R Development Core Team 2007: $R$ : A Language and Environment for Statistical Computing. R Foundation for Statistical Computing, Vienna. Available via DIALOG: http://www. R-project.org.

RedDell J. \& CoKendolPher J. 1995: Catalogue, bibliography, and generic revision of the order Schizomida (Arachnida). Texas Mem. Mus. Speleol. Monogr. 4: 1-170.

RYBAK J. 2007: Life history of Bathyphantes simillimus (Araneae: Linyphiidae) in Stołowe Mountains, Poland. Acta Zool. Cracov. (B) 50(2): 83-90.

Schaefer M. 1987: Life cycles and diapause. In Nentwig W. (ed.): Ecophysiology of Spiders. Springer, Berlin, pp. 331-347.

Shimojana M. \& Nishinira M. 2000: A new cavedwelling eyeless spider of the genus Coelotes (Araneae: Amaurobiidae) from Okinawa Island, the Ryukyu Islands, Japan, with notes on possible parthenogenesis. Acta Arachnol. 49: 29-40.

SimON E. 1891: On the spiders of the Island of St. Vincent. Part 1. Proc. R. Soc. Lond. 1891: 549-575.
Simpson M.R. 1995: Covariation of spider egg and clutch size: the influence of foraging and parental care. Ecology 76: 795-800.

SuOMALAINEN E. 1962: Significance of parthenogenesis in the evolution of insects. Annu. Rev. Entomol. 7: 349-366.

TANAKA K. 1992: Size-dependent survivorship in the webbuilding spider Agelena limbata. Oecologia 90: 597-602.

Therneau T. \& Lumley T. 2007: Survival: Survival Analysis, Including Penalised Likelihood. R Package Version 2.29. R Foundation for Statistical Computing, Vienna.

TSURUSAKI N. 1986: Parthenogenesis and geographic variation of sex ratio in two species of Leiobunum (Arachnida, Opiliones). Zool. Sci. 3: 517-532.

VRIJENHOEK R.C. 1979: Factors affecting clonal diversity and coexistence. Am. Zool. 19: 787-797.

Weeks A.R, Reynolds K.T. \& Hoffmann A.A. 2002: Wolbachia dynamics and host effects: what has (and has not) been demonstrated? Trends Ecol. Evol. 17: 257-262.

Weygoldt P. 2007: Parthenogenesis and reproduction in Charinus ioanniticus (Kritscher, 1959) (Chelicerata, Amblypygi, Charinidae). Bull. Br. Arachnol. Soc. 14: 81-82.

White M.J.D. 1973: Animal Cytology and Evolution. Cambridge University Press, New York, viii + 961 pp.

Zchori-Fein E. \& PerLman S.J. 2004: Distribution of the bacterial symbiont Cardinium in arthropods. Mol. Ecol. 13: 2009-2016.

Received January 8, 2009; revised and accepted February19, 2009 